\title{
Surge of Bering Glacier and Bagley Ice Field, Alaska: an up- date to August 1995 and an interpretation of brittle- deformation patterns
}

\author{
Ute Christina Herzfeld, ${ }^{1,2}$ Helmut Mayer ${ }^{2}$ \\ ${ }^{1}$ Geomathematik, Fachbereich Geowissenschaften, Universität Trier, D-54286 Trier, Germany \\ ${ }^{2}$ Institute of Arctic and Alpine Research, University of Colorado, Boulder, Colorado 80309, U.S.A.
}

\begin{abstract}
In the summers of 1993, 1994 and 1995, video and Global Positioning System location data and $35 \mathrm{~mm}$ photographs were collected in a series of systematic survey flights undertaken over the Bering Glacier and Bagley Ice Field system (Alaska) in an effort to characterize surge-crevasse patterns and surge propagation. During survey flights in late August 1995, we observed that the 1993-94 Bering Glacier surge was continuing and still expanding, affecting new areas farther up in Bagley Ice Field. New crevasse fields, similar in pattern to the first surge crevasses we had observed in June 1993 below Khitrov Hills and in other isolated areas of central Bering Glacier and in July 1994 near the head of Bering Glacier (near the junction of Bering Glacier and Bagley Ice Field, in both upper Bering Glacier and Bagley Ice Field), were opening in eastern Bagley Ice Field and in the "Steller" side of Bagley Ice Field. The type of crevasses seen in the new fields suggested that the surge was propagating into these areas. By analysis and interpretation of the brittle-deformation patterns apparent in the crevasse patterns, some aspects of the past kinematic framework of the surge can be deduced. This approach may lead to a more general classification of ice-surface structures and to their linkage to ongoing processes.
\end{abstract}

\section{INTRODUCTION}

Bering Glacier, Alaska's longest glacier, started to surge sometime between 13 May 1993, when R. Krimmel observed no surge crevasses and 13-14 June 1993, when A. Post, C. Lingle and U. C. Herzfeld noticed fresh surge crevasses. As new surge crevasses, we define fields of freshly opened crevasses with characteristically sharp and uneroded edges, indicative of recent extensive, substantial and fast ice deformation.

Due to its size and complexity, the Bering Glacier/Bagley Ice Field system comprises several glaciers named independently during the discovery of Alaska and Canada, including Bagley Ice Field, Columbus Glacier, Quintino Sella Glacier, Jefferies Glacier and Steller Glacier (Molnia and Post, 1995; cf. Fig. 1). Columbus Glacier originates west of the King-Logan Massif and joins Quintino Sella Glacier to form Bagley Ice Field, which follows a large $(7.5-12 \mathrm{~km}$ wide) trough in the Chugach Mountains to the west. Tana Glacier drains northward from the ice field, while Bering Glacier, the largest glacier flowing out of Bagley Ice Field, drains to the southwest through a trough $13 \mathrm{~km}$ wide. Bering Glacier and Bagley Ice Field may be considered as one glacier, the Bering-Bagley system, which has a length of close to $200 \mathrm{~km}$.

Whereas Bering Glacier surges quasi-periodically about every $20+$ years, the neighbouring Steller Glacier, which is also an arm of Bagley Ice Field, does not surge (Post, 1972). Bering and Steller Glaciers form a large piedmont lobe, about $50 \mathrm{~km}$ wide, which terminates in a chain of proglacial lakes. These lakes are separated from the Gulf of Alaska by a narrow stretch of coast, in one place by a sand spit only $200 \mathrm{~m}$ wide (Seal River Spit). Over-riding of the spit by the ice front would transform Bering Glacier into a tide-water glacier and induce a rapid and drastic change in the entire coastal environment, causing rapid back-stepping erosion of the young over-ridden sediments, and possibly reconnecting the deep trough under present-day Bering Glacier to its offshore continuation (cf. Meier and Post (1987) for processes involved). The difference in dynamics and mass equilibrium between Bering and Steller Glaciers is documented by folded medial moraines which have recorded surges during the last 500 years (Molnia and Post, 1995). During a surge, the Bering-Steller Glaciers' medial moraine is pushed towards the Steller Glacier side. With decreasing velocity of Bering Glacier after the surge, the Steller Glacier ice flow increases in relative strength and the medial moraine is relocated towards the Bering Glacier side. The difference in the rate of change in velocity (sudden increase in speed at the beginning of the surge vs slow decrease of speed at the end) is reflected in the asymmetry of the folded moraines. It is not clear why Bering Glacier surges and Steller Glacier does not. In this context, the question arises whether Bagley Ice Field surges and how far the surge-affected ice extends.

During the entire surging period, Bering Glacier has been in a state of retreat from its Holocene maximum position (Molnia and Post, 1995). The rapid surge advances are superimposed on the overall retreat.

The progress of the recent surge has been documented in a number of news notes and correspondences. The surge 


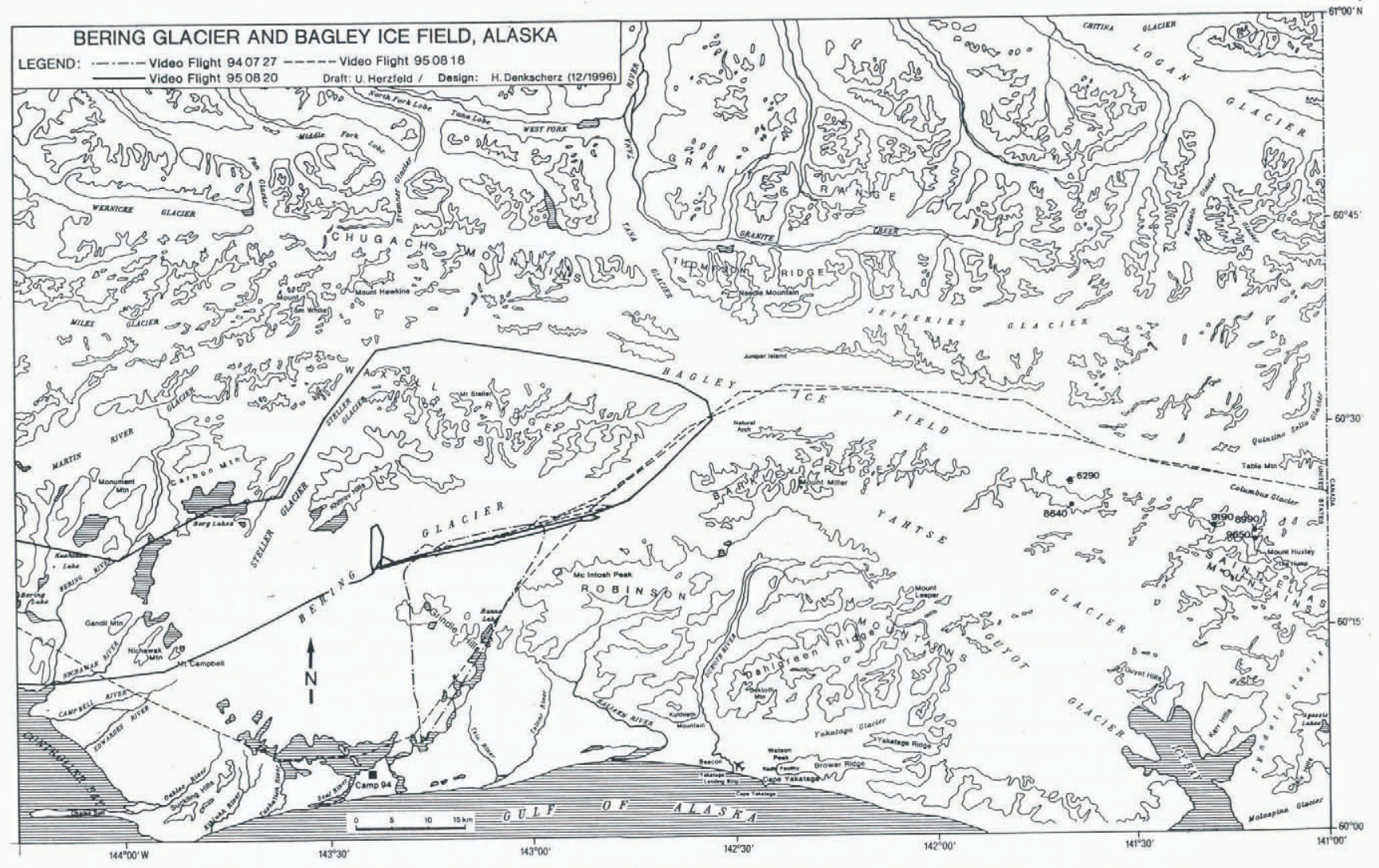

Fig. 1. Flight tracks of 27 July 1994, and 18 and 20 August 1995, on a topographic map of the Bering Glacier/Bagley Ice Field area, Alaska (modified after United States Geological Survey, 1983).

reached the ice front on 23 August 1993 (Molnia, 1993), causing rapid advance of the central part of the terminus (1500 $\mathrm{m}$ in 17 days) but rapid retreat of the terminus in the Tasalish Arm $\left(25 \mathrm{~m} \mathrm{~d}^{-1}\right)$ and in a neighbouring area, both in the western ice front. Terminus advance in 1994 was monitored by Fleisher and others (1995). By 1994, the surface of Bering Glacier had become totally crevassed and the surge was propagating into Bagley Ice Field.

Throughout the Bering Glacier surge, the dynamics were complex with fast motion propagating into different areas at different times; and with the areas of greatest speed changing as the surge progressed. We attribute this to the probably complex subglacial topography and to the enormous size of the Bering Glacier system, encompassing several flows and catchment areas. The advance varied regionally, i.e. from one glacier region to another.

In contrast to the situation in the well-prepared study of the Variegated Glacier surge (Kamb and others, 1985; Raymond, 1987), only few geophysical data are available for the Bering Glacier surge. Hydrographic and glaciologic data of the glacier at a quiescent stage are generally lacking, with a few exceptions (cf. Fleisher and others, 1995; Molnia and Post, 1995; and references therein). Subglacial topography influences the location of crevasse fields but unfortunately not many soundings of Bering Glacier are available (personal communication from D. Trabant). In part, the size of the Bering Glacier-Bagley Ice Field system has prohibited comprehensive ground-based geophysical study. This fact, which impedes "classical" geophysical investigations, constitutes both a challenge and an opportunity for investigations based on remote-sensing data.

The basic idea of our analyses is to exploit the relationships between movement in time (surge propagation and stress field) and frozen movement (crevasse patterns and strain), and thus to reconstruct the stress field from the observed patterns, as exemplified in the section on "structural geology in ice". The structural analysis then aids in conclusions on the propagation of the surge. Geophysical questions addressed with this approach are: how does surface roughness relate to ice velocity, to the flow field, and to stress and surge propagation? How does this ultimately influence calving?

In addition, surface classification by visual inspection, and structural interpretation as demonstrated in this essay for a few examples, provide the basis for the discrimination of classes of crevasse types for an automated geostatistical ice-surface classification based on remote-sensing data (Herzfeld, 1993, in press; Herzfeld and others, 1996a, b).

In the 1994 and 1995 field experiments, we collected video data and Global Positioning System (GPS) data from small aircraft. GPS data are used for geolocation of the video data and of photographs, and allow comparison of video data with satellite Synthetic Aperture Radar (SAR) data from ERS-1 (European Space Agency). Video data are collected to study surface structures at high resolution and to do so automatically, and are preferable to photographs for digital evaluation.

Geostatistical surface classification provides a robust technique for the analysis of complex movement. Interferometry is not applicable to the surge, because the ice movement leads to a lack of correlation between SAR images (Fatland and Lingle, 1994). From the perspective of providing ground truth for the analysis of SAR data, the Bering Glacier surge has presented a unique opportunity to sample and characterize the surface of catastrophically accelerating ice and rapid changes in surface roughness. 
On 27 August 1994, a jökulhlaup (catastrophic water outburst) started; this event was generally considered to mark the end of the surge (Molnia, 1994; Fleisher and others, 1995). During a week of exceptionally clear weather in the rainy 1995 summer season, we undertook two flights, during which photography and video data were co-registered with GPS data, to investigate the current (18 and 20 August 1995) state and extent of the surge. The visual analysis in this essay is documented by the sharper $35 \mathrm{~mm}$ photographs, taken on the same flights as the videos and also GPS registered. We now use these observations to address the following questions:

(1) Does Bagley Ice Field surge?

(2) Where in the Bagley Ice Field-Bering Glacier-Steller Glacier system is the boundary between surging and non-surging ice?

(3) Does a flood outburst generally mark the end of a surge?

(4) How do surges propagate?

These questions relate to more general questions formulated by Raymond (1987):

(a) What is the mechanism of fast motion during a surge?

(b) What initiates and terminates the fast motion?

The Variegated Glacier study (Kamb and others, 1985) provided important data needed to answer these questions but the surge mechanisms are still not fully understood. Bering Glacier provides an example of an observed surge in a much larger glacier in a climatic setting similar to that of Variegated Glacier.

\section{ADVANCE OF SURGE FRONT}

By the summer of 1995, the surge had continued to propagate farther into Bagley Ice Field. New surge crevasse fields (Figs 2 and 3) occurred as far east as $141^{\circ} 10^{\prime} \mathrm{W}$. In the crevasse field opposite east Barkley Ridge (near $60^{\circ} 30^{\prime} \mathrm{N}$, $141^{\circ} 50^{\prime} \mathrm{W}$ ) in Bagley Ice Field, crevasses opened in a direction different from that of pre-existing ones, creating seracs with square, pentagonal or hexagonal tops (Fig. 2). This resembles the situation in central Bering Glacier in June 1993

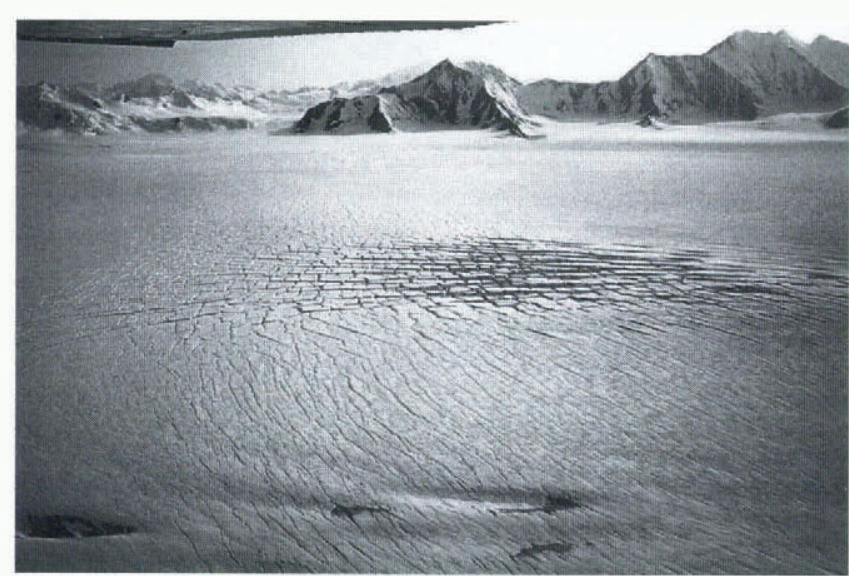

Fig. 2. New surge activity indicated by fresh crevasses superimposed on older crevasses in eastern Bagley Ice Field, opposite east Barkley Ridge $\left(60^{\circ} 30^{\prime}\right.$. N, $141^{\circ} .50^{\prime}$ W); 18 August 1995.

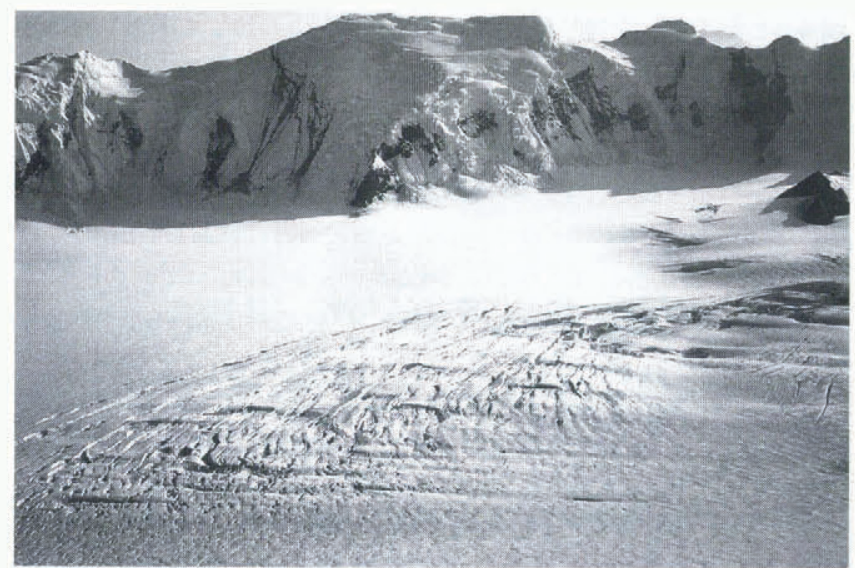

Fig. 3. New surge crevasses cross-cut old topographically induced crevasses off spur 6290 on 8640 ridge at $60^{\circ} 25^{\prime} \mathrm{N}$, $141^{\circ} 40^{\prime} \mathrm{W}$; 18 August 1995.

at the beginning of the surge (cf. figs 2, 3 and 4 in Lingle and others, 1993) and is typical of a surge front propagating into ice previously not affected by the surge. Fresh en-échelon surge crevasses as existing in central Bering Glacier in 1993 are depicted in Figure 4.

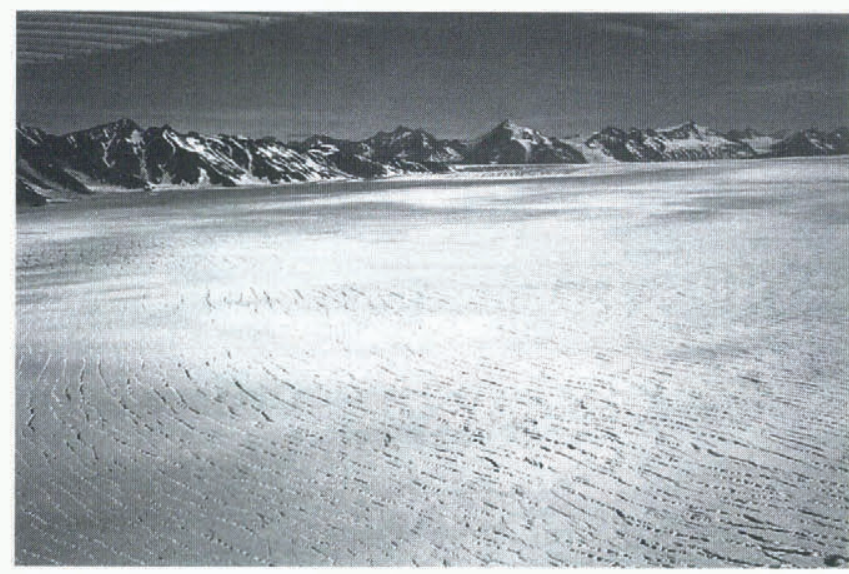

Fig. 4. Fresh surge crevasse field in central Bering Glacier on 24 June 1993. Compare to Figure 2 and Figures 9 and 10.

Figure 3 shows the surge crevasse field located farther east (upstream in Bagley Ice Field/Columbus Glacier) in August 1995, at about $60^{\circ} 25^{\prime} \mathrm{N}, 141^{\circ} 40^{\prime} \mathrm{W}$ at the foot of the rock spur that contains point 6290 on the USGS 1:250 000 topographic map "Bering Glacier, Alaska" and leads off the ridge labeled " 8640 " on the map (we call this one " 8640 ridge" for short). Here, the rock spur at the base of the ridge probably continues subglacially and induces extensional deformation in the ice. This is the effect of topographically induced stress, i.e. the stress acting on the ice sheet at a point where it flows against a topographic obstacle, for example, a mountainside or a rock spur, creating strain features in the ice such as crevasses oriented radially around the obstacle. The photograph depicts both crevasses of topographic origin and surge crevasses. The difference in stress direction is apparent in the angle between the trends of the two sets of crevasses. Crevasse fields of this type - surge-related new crevassing opening up in an area of topographically induced stress - appeared as far east as $60^{\circ} 23^{\prime} \mathrm{N}, 141^{\circ} 20^{\prime} \mathrm{W}$ off the third rock spur that descends from point 9190 on the USGS map (cf. Fig. 1) and off the fork-shaped rock spur that descends off Mount Huxley via points 9650 and 8990 to Columbus Glacier (near $141^{\circ} 10^{\prime} \mathrm{W}$ ). 


\section{STAGES OF SURGE EXEMPLIFIED BY CREVASSE PATTERNS}

In our analysis, we use the following terminology: (a) beginning surge stage: early summer 1993, few crevasse fields; (b) mature surge stage: after surge reached terminus in 1993 and summer 1994; (c) late-surge stage: after onset of the water outburst during August 1994, continuing through August 1995.

Bagley Ice Field in 1995 was reminiscent of Bering Glacier in 1993 and of the Bering Glacier/Bagley Ice Field area in 1994 - a smooth ice stream into which the surge was just propagating, as indicated by discrete surge-crevasse fields several tens of kilometres apart. Our observations in the three seasons revealed that the surge propagated upglacier and down-glacier from a starting point in the lower central Bering Glacier (below Khitrov Hills; cf. Lingle and others, 1993, fig. 5), and that crevasse patterns followed typical successions, indicative of the change in the stress and velocity fields, as the surge continued. The movement is literally frozen in ice: a record of the movement is contained in the crevasse patterns and the patterns are characteristic of the surge activities. This suggests that it is possible to characterize the succession of surge stages and related crevasse patterns, and to use them in a classification of the ice surface. Such a classification may be applied to reconstruct the stress and velocity fields of past surge stages.

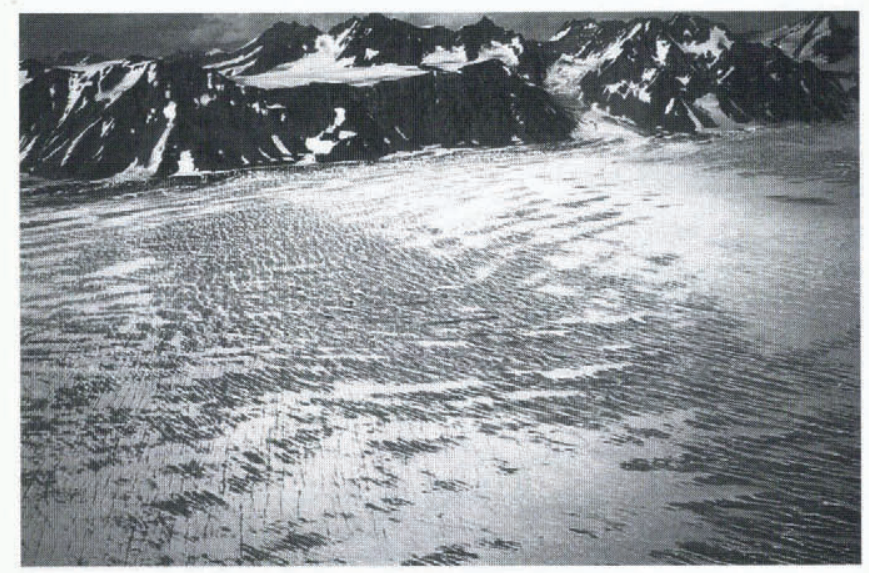

Fig. 5. Later stage of surge in Bagley Ice Field, with old and new crevasses and water, near Juniper Ridge; 18 August 1995.

Figure 5 shows an area that was first affected by the surge in the summer of 1994 (located in Bagley Ice Field nearJuniper Ridge, in the background). The previous year's crevasses have taken on a wavy shape and are, in part, filled with clear blue water. Newer (1995) crevasses trend across the glacier at about $45^{\circ}$ to the 1994 crevasses. New crevasses intersect the snow cover, whereas patches of melting snow adhere to the ridges between old crevasses.

High water levels in a glacier are typical of the mature stage of a surge. They indicate that the crevasses are not, or no longer, connected to the bottom. In the lower part of the fast-flowing glacier, water conduits are apparently shut off regionally. No turbid water is expelled from the bed to the surface nor is the clear surface meltwater effectively drained. Even more so than in 1994, in the summer of 1995 large areas of central Bering Glacier appeared to be flooded by water (Fig. 6). Despite the occurrence of the large outburst in late August 1994, the water level in Bering Glacier

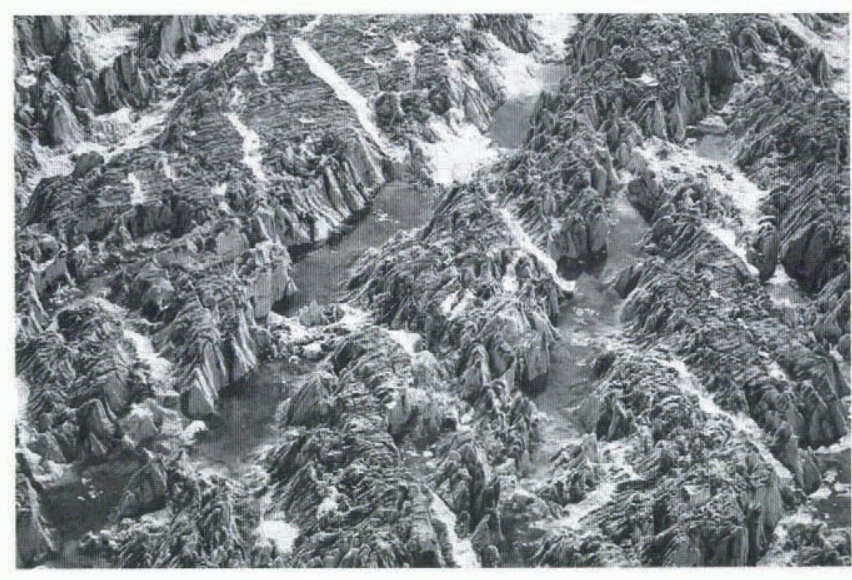

Fig. 6. Survey area, central Bering Glacier. The high water level in the crevasses is typical of the late stages of a surge; August 1995.

and parts of Bagley Ice Field was higher in 1995 than in 1994. This indicates that there are several distinct water systems in the glacier. In our flight of 18 August 1995, we noticed upwelling in several places in the area of the jökulhlaup. According to the local pilots, who frequently flew over the glacier and observed its activity, water had continued to drain from this area after August 1994 but at a rate lower than the initial rate.

Observation and analysis of strain patterns as evident in the crevasse patterns facilitates the deduction of some aspects of the kinematic framework in which these crevasses formed. The ice surface in Figure 6 shows the signature of several surge-deformation phases: shear patterns and extensional patterns, overprinting an undulating ice surface. At least three processes can be distinguished: 1. Shear, indicated by offsets along two main crevasse directions at oblique angle; 2. Extension, indicated by densely spaced crevasses; and 3. Extension, indicated by widely spaced large crevasses filled with water and fallen seracs. Several strain fields adjacent to each other can be distinguished in the crevasse patterns of Figure 7 taken in the survey area in central Bering Glacier. In the foreground of the photograph, there are: 1. Block structures; 2. Cross-cutting crevasses; and 3. Wavy crevasses and water-filled gaps formed by extension. In the background, we see boundaries delineating different strain patterns.

Figure 8 shows the location where the surge started in

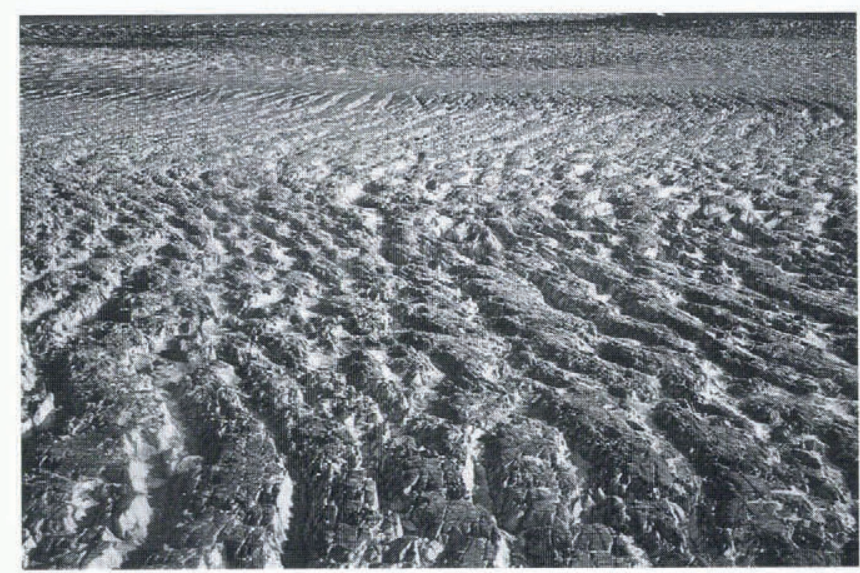

Fig. 7. Survey area, central Bering Glacier. Old wavycrevasses resulting from superposition of several deformation phases. High water level; August 1995. 


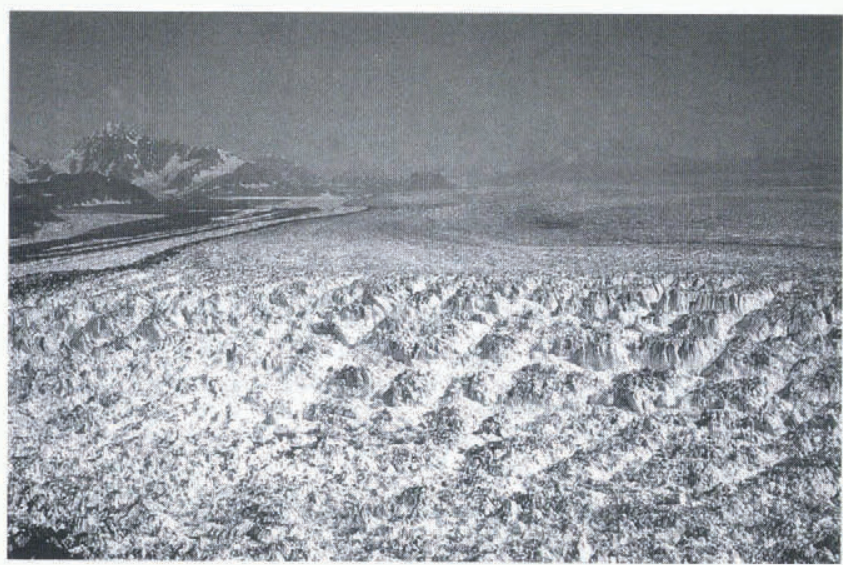

Fig. 8. Area where the surge first started in 1993, below Khitrov Hills, as it appeared in August 199.5.

June 1993, below Khitrov Hills (cf. figs 5 and 6 in Lingle and others, 1993). It is impossible to distinguish individual crevasse lines or surge-deformation phases. Most seracs have fallen over, leaving islands of standing or leaning seracs, arranged in an approximately square pattern, with a maze of seracs in the foreground.

\section{STRUCTURAL GEOLOGY IN ICE}

Crevasse patterns on the glacier surface reveal strain states. Strain state is defined as a particular state of deformation resulting from the process of deformation. Furthermore, crevasses reveal strain histories by their cross-cutting and overprinting relationships. In a kinematic framework, these strain patterns allow the reconstruction of stress fields and their changes.

Figure 9 shows old (1993 or/and 1994) crevasses with a typical pattern of two approximately orthogonal directions (two-directional pattern), indicative of a later stage of the same process that created the strain pattern in Figure 2. The two-directional pattern dominated the surface of central Bering Glacier in July and August 1994. This indicates that the ice mass had been affected, in the course of the surge up to that time, by at least two distinct deformational events characterized by different stress-field orientations.

Figure 10, taken in eastern Bagley Ice Field near the Jeff-

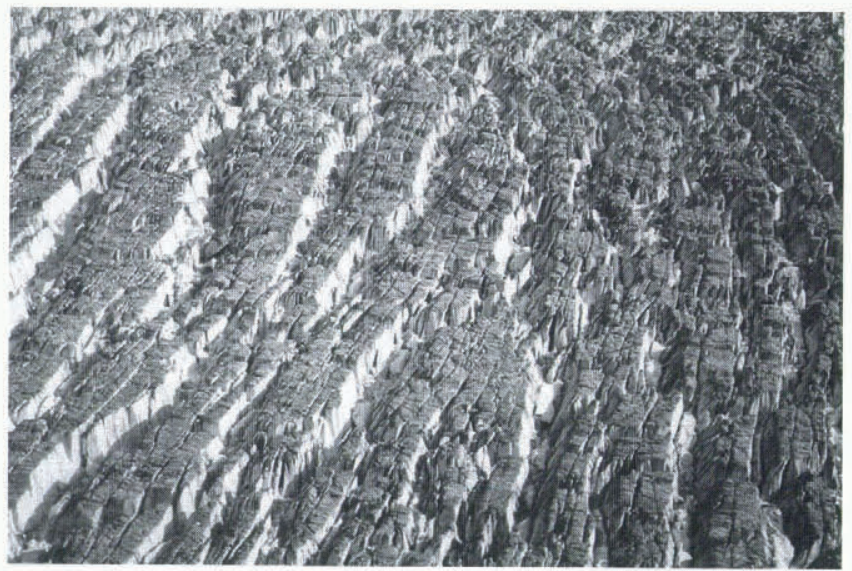

Fig. 9. Old (1994) two-directional crevasses on Bering Glacier; August 1995.

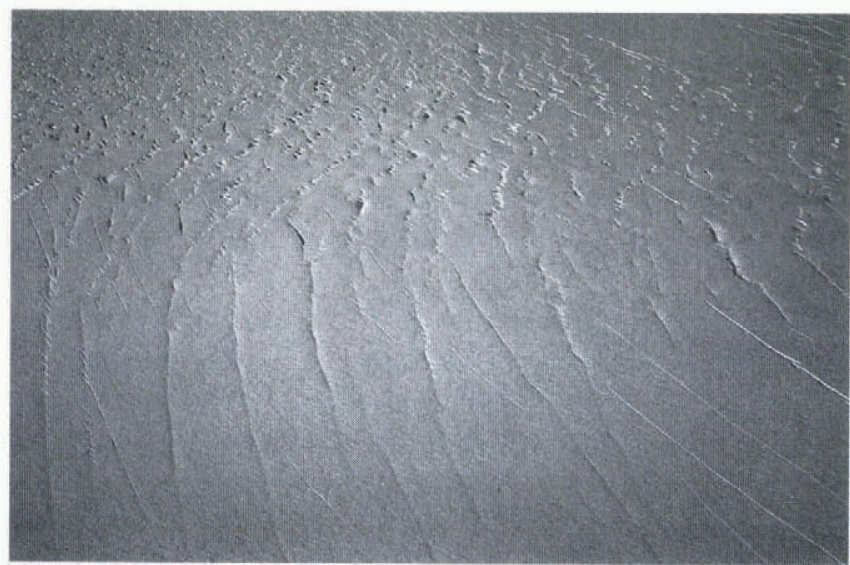

Fig. 10. Fresh en-échelon crevasses in eastern Bagley Ice Field (near Fefferies Gap) indicating the contemporary propagation of the surge into this area; 18 August 1995.

eries Glacier gap ( $\left.141^{\circ} 45^{\prime} \mathrm{W}\right)$, gives an excellent example of en-échelon structures. These are the first manifestations of a change in stress-field orientation. The older direction is indicated by crevasses that trend in the view direction. In the foreground, they are covered by snow. The younger direction is at about $30^{\circ}$ to the older direction (crevasses depicted by thin sharp lines). Only relative ages can be determined by this method. Some measure of age difference can be estimated from the differences with respect to snow cover and eroded or degraded edges but this is hard to quantify. The stress of the second generation is broken and deflected at the old lines of weakness, forming the en-échelon patterns. This is exactly what is seen in the oceanic crust when transform faults re-orient themselves parallel to the new spreading direction when a change of plate motion occurs along mid-oceanic ridges (e.g. Macdonald, 1982).

We also observed fresh crevassing on the "Steller" side of Bagley Ice Field (Fig. 11). Figure 11 is, in principle, an example of the same situation as Figure 10, showing a composite strain resulting from two deformation events that occurred at different times but with a different relative spacing of the crevasse systems, which intersect at a $40^{\circ}$ angle. The stress seems to have been propagated along an old crevasse line for a distance almost equal to the spacing of the old crevasses. A new crevasse is then created, connecting two adjacent old ones; this process leads to fairly regular zigzag lines of fracture. The feathery en-échelon pattern of the previous example is rarely seen in this image.

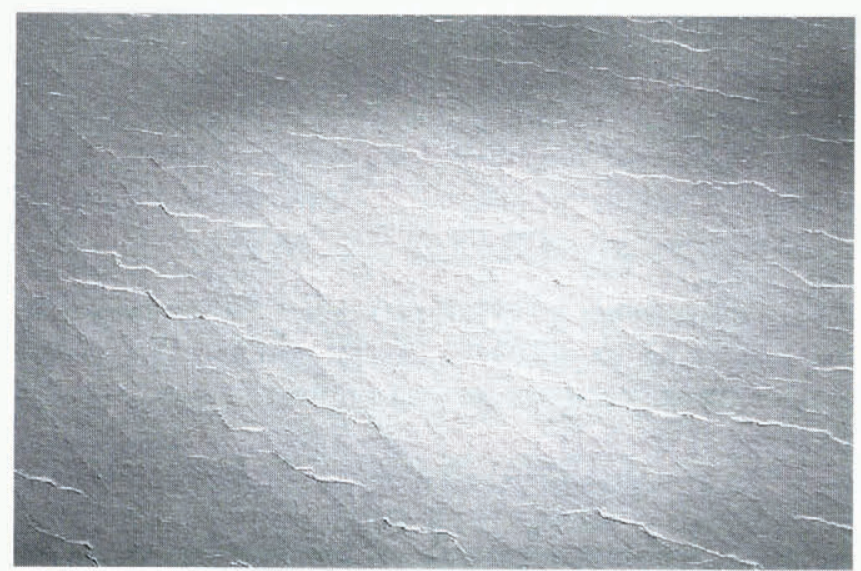

Fig. 11. Fresh surge crevassing superimposed on older crevasses on the Steller Glacier side of Bagley Ice Field; 20 August 1995. 
Our preliminary analyses indicate that certain crevasse patterns are characteristic of certain surge phases and are preserved in the ice. Contiguous areas of specific patterns lend themselves to (automated) surface classification (Herzfeld, in press), thus permitting the reconstruction of the areal extent of surge phases and the kinematic evolution of the surge.

Deformation patterns of ice surfaces may be used to study forces and processes in glaciers or ice sheets analogous to those active in the Earth's lithosphere, and have been an objective of structural-geological analysis in a few instances (e.g. Allen and others, 1960; Meier, 1960; Hambrey and Milnes, 1977). In their paper entitled "Structural geology of an Alpine glacier (Griesgletscher, Valais, Switzerland)", Hambrey and Milnes (1977) produced a structural map of Griesgletscher with pole diagrams and analyses of strain (foliation, crevasse traces in glacier ice, en-échelon zones, boudins and mylonite zones). Those authors focused on ductile deformation in the deeper levels of an Alpine glacier exposed in the ablation zone. The processes involved correspond to those occurring at a deep crustal level during orogenetic deformation.

In this paper we are concerned with the brittle deformation apparent in surface crevasse patterns of a surging glacier. The surge-type crevasse patterns of Bering Glacier correspond to extensional faulting in upper crustal levels. The elongated blocks separated by parallel crevasses and the en-échelon crevasses are reminiscent of faults in young oceanic crust, such as those in the abyssal hill terrain on the flanks of the slow-spreading Mid-Atlantic Ridge (Tucholke and Lin, 1994; Herzfeld and Higginson, 1996) and in their corresponding subaerial surfaces as they occur in Iceland, for instance. A good example is the Almannagjá and its surroundings in Iceland. Brittle deformation patterns observed on Bering Glacier during the surge not only resemble brittle crust deformation features visually, but are also characterized by the same types of parameters in automated geostatistical surface classification, as used for an example from the western flank of the Mid-Atlantic Ridge near $46^{\circ} \mathrm{N}$ (Herzfeld and Higginson, 1996). These observations and comparison with the work on Griesgletscher (Hambrey and Milnes, 1977) suggest a velocity analogy between different tectonic environments and types of glacier dynamics:

(1) Metamorphic deformations - ductile deformation at lower-crust temperature and high lithostatic pressure - basal parts of an Alpine glacier (Griesgletscher).

(2) Deformation of newly generated oceanic crust of Atlantic (slow-spreading) type - upper-crust brittle deformation (mainly extensional) - disintegration of a large glacier during a surge (Bering Glacier).

Can this analogy be extended further? For instance, fastspreading-type oceanic-crust deformation may correspond to the dynamic deformation in fast-flowing ice streams and glaciers.

If the analogies proposed here can be confirmed, they can be exploited, on the one hand, to learn more about crustal deformation, since ice deformation operates on shorter time-scales. The longer record of dynamic deformation in crustal rocks, on the other hand, will provide us with new ways of understanding glacier and ice-sheet dynamics.

\section{BOUNDARIES OF SURGE-AFFEGTED ICE IN BAGLEY ICE FIELD}

Bering Glacier is part of the Bering Glacier-Bagley Ice Field system regarding glacial dynamics. Although it has long been known that Bering Glacier surges quasi-periodically and that Steller Glacier does not (Post, 1972), it was not known until the 1993-95 surge whether Bagley Ice Field is affected by surging, and if so, which parts of it. In 1994, the surge had propagated just into Bagley Ice Field at the outflow of Bering Glacier and some distance eastward (below Mount Miller, to about $142^{\circ} \mathrm{W}$ ).

Observations during our survey flight on 18 August 1995 revealed that the easternmost field of surge-related crevasses was located near $141^{\circ} 10^{\prime} \mathrm{W}$, as mentioned above. The occurrence of new crevasses in Bagley Ice Field in the late surge stage may have resulted from an upflow transmission of stress relief and kinematic effects from the surge, explained by the following mechanism: the mass transfer from the anomalous ice build-up (as explained in the model of Fowler (1987)) typical of the onset of the surge causes a deficit of mass in neighbouring areas, which in turn induces further mass transfer and velocity increase up-glacier from the starting point of the surge. The deficit of mass leads to a decrease in upward or back-holding force, which induces tensile stress in flow direction resulting in new crevassing. By a continuation of this mechanism, the surge "propagates up-glacier". We attribute the fresh crevasse fields near $141^{\circ} 10^{\prime} \mathrm{W}$ to this effect, which is part of the surge. In this sense, the field of surge crevasses farthest east marks the eastern limit of the extent of the surge (at time of observation).

To establish the western limit of the surge-affected ice, we investigated western Bagley Ice Field and Steller Glacier, an area that is seldom visited, on 20 August 1995. The boundary between the eastern "Bering" side and the western "Steller" side of Bagley Ice Field is the junction with Bering Glacier. The new generation of crevasses depicted in Figure 11 (described in the previous section) is attributed to the same effect of up-glacier-propagated stress relief as the crevasse fields near $141^{\circ} 10^{\prime} \mathrm{W}$. Because Figure 11 was taken about $15 \mathrm{~km}$ west of the western corner of the Bagley Ice Field-Bering Glacier junction, the western boundary of surge-affected ice was located in the "Steller" side of Bagley Ice Field in August 1995.

\section{OBSERVATIONS ON STELLER GLACIER}

Steller Glacier itself did not show surge-related crevasses. As an exception, we noted minor fresh crevassing in two areas in Steller Glacier on 20 August 1995. Some fresh crevasses in Steller Glacier close to the folded medial moraine between Bering and Steller Glaciers might have resulted from the push of the surging Bering Glacier transmitted across the medial moraine. During a surge, the entire system Bagley Ice Field-Bering Glacier-Steller Glacier is out of equilibrium and not all of this is compensated for by the (rather slow) dislocation of the folded moraine, as described by Post (1972). In another possible interpretation, this lower crevasse field may be attributed to the retreat of Tasalish Arm (interpretation by A. Post (personal communication, January 1997)).

Minor fresh crevassing observed in upper Steller Glacier and in the aforementioned location next to the Bering 
Glacier-Steller Glacier moraine may also be the result of a "pulse" of Steller Glacier at the time. This interpretation derives from the observations of A. Post (personal communication, January 1997) that Steller Glacier "pulses" more frequently than Bering Glacier surges, with the latest "pulse" in 1993-94 being most active in the Steller Glacier valley. In summary, there are three possible reasons for fresh crevassing in Steller Glacier: (1) induction by the Bering Glacier surge, (2) pulsing of Steller Glacier and (3) retreat of Tasalish Arm.

\section{CONCLUSIONS}

Observations of Bering Glacier and Bagley Ice Field with video and GPS data collected from small aircraft and aerial photography aided in answering the questions intially posed: (1) Large parts of Bagley Ice Field are affected by the surge. (2) The eastern boundary of surge-affected ice is located at least as far east as $141^{\circ} 10^{\prime} \mathrm{W}$ (near Mount Huxley), the western boundary about $15 \mathrm{~km}$ west of the Bering Glacier-Bagley Ice Field corner (or possibly farther west). (3) The surge propagated from a starting point in lower central Bering Glacier both up-glacier and down-glacier. (4) The up-glacier propagation of fresh surge crevassing continued for at least 12 months after a major water outburst which started on 27 August 1994 and continued with a decreased discharge through August 1995.

The ice displacement is probably initiated at the location of largest build-up of anomalous ice following the model of Fowler (1987); after this ice has been transported to the receiving area, the upstream pressure component induced by the anomalous ice loading in the central part decays, which releases waves of material for transport down-glacier from areas farther upstream. This process continues after the main surge activity in the mature stage of the surge. It is interesting to note that in the late surge stage the surge front is still advancing in both east and west directions in Bagley Ice Field, while at the same time only local surge activity is observed in the central, heavily crevassed parts that were affected by the surge during the mature stage.

Analogies with brittle-deformation patterns from structural geology are employed in crevasse-pattern classification and automated in a geostatistical surface classification method (Herzfeld, in press) in an effort to reconstruct stress fields during surge propagation and to learn about the relationships between surface roughness, velocity, stress and strain during a surge. Not only may techniques and insights from structural geology be applied, analogies of deformation types are obvious. Slowly changing alpine glaciers exhibit ductile deformation patterns similar to orogenetic metamorphic processes. Crevassing of Bering Glacier, during the surge, is reminiscent of crustal deformation in slow-spreading oceanic ridges rather than in fast-spreading ones, and a similar classification scheme applies. Examples of applications in a regime of brittle deformation (on the western flank of the Mid-Atlantic Ridge) have been given by Herzfeld and Higginson (1996).

Glaciologists have considered surge glaciers a different species from non-surging glaciers, because surge glaciers switch from one dynamical state into another. In the sense of a catastrophe model, this is not necessarily the case. The study of systems where continuous input leads to discontinuous events (catastrophes) is the objective of catastrophe theory, a branch of algebraic topology. The catastropheclassification theorem, proved in the mid-1960s by R. Thom (1972; cf. Poston and Stewart, 1978, p. 99-122), states that any catastrophe is described by one of seven types of catastrophe manifolds. There are catastrophe manifolds that encompass a continuous transition from one set of parameters characteristic of a system that has only continuous properties to a set of parameters characteristic of a system that switches states. In this sense, we hypothesize that surge-type glaciers may be considered intermediate in their dynamics between "normal" (non-surging) glaciers and fast-flowing ice streams (cf. Fowler, 1987; Raymond, 1987). We showed that the dynamic deformation during surges is akin to brittle deformation in slow-spreading oceanic ridges. Developing this analogy between dynamic ice systems and dynamic crust systems further, we suggest that deformation in continuously fast-moving ice streams may be analogous to brittle deformation in fast-spreading ocean-ridge environments.

\section{ACKNOWLEDGEMENTS}

Many thanks to everyone who provided help and unforgettable memories, in particular to S. and G. Ranney of Fishing and Flying, Cordova, Alaska, R. Carlson of Era Helicopters, Anchorage, Alaska, to B. Molnia for the opportunity to participate in the USGS field camp 1994, to A. Post and D. Trabant for valuable discussions (all U.S. Geological Survey), to J. Roush (University of Alaska, Fairbanks) and K. Lohuis (Albion College) for field assistance in 1994, to K. Steffen (University of Colorado, Boulder) for use of a GPS receiver in 1995, to H. Denkscherz (Universität Trier) for drafting the map of Figure 1, to R. Leb. Hooke (University of Minnesota, Minneapolis), D. R. MacAyeal (University of Chicago), C. Raymond (University of Washington, Seattle), and J. Hollin (University of Colorado, Boulder) for helpful comments on the manuscript. The project has in part been supported through NASA Office of Polar Programs grant NAGW-3790, U.S. DOE grant DE-FG03-93ER61689 (Principal Investigator M. F. Meier) and Deutsche Forschungsgemeinschaft through a Heisenberg Fellowship to $\mathrm{UCH}$.

\section{REFERENCES}

Allen, C. R., W. B. Kamb, M. F. Meier and R. P. Sharp. 1960. Structure of the lower Blue Glacier, Washington. J. Geol., 68 (6), $601-625$.

Fatland, D. R. and C. S. Lingle. 1994. The surface velocity field on Bagley Icefield, Alaska, before and during the 1993-94 surge of Bering Glacier, from ERS-1 SAR interferometry. [Abstract.] EOS, 75 (44), Supplement, 62.

Fleisher, P.J. and 6 others. 1995. Correspondence. The surging advance of Bering Glacier, Alaska, U.S.A.: a progress report. f. Glaciol., 41 (137), 207213.

Fowler, A. C. 1987. A theory of glacier surges. J. Geophys. Res., 92 (B9), 9111-9120. Hambrey, M. J. and A. G. Milnes. 1977. Structural geology of an Alpine glacier (Griesgletscher, Valais, Switzerland). Eclogae Geol. Helv., 70 (3), 667-684.

Herzfeld, U. C. 1993. A method for seafloor classification using directional variograms, demonstrated for data from the western flank of the MidAtlantic ridge. Math. Geol., 25 (7), $901-924$.

Herzfeld, U. C. In press. Geostatistical interpolation and classification of remote-sensing data from ice surfaces. Int. J. Remote Sensing.

Herzfeld, U. C. and C. A. Higginson. 1996. Automated geostatistical seafloor classification - principles, parameters, feature vectors, and discrimination criteria. Comput. Geosci., 22 (1), 35-52.

Herzfeld, U. C., H. Mayer, C. A. Higginson and M. Matassa. 1996a. Geostatistical approaches to interpolation and classification of remote-sensing data from ice surfaces. In Fourth Circumpolar Symposium on Remote Sensing of the Polar Environments, 29 April - 1 May 1996, Lyngby, Denmark. Noordwijk, European Space Agency, 59-63. (ESA SP-391.). 
Herzfeld, U. C., O. Zahner, H. Mayer, C. A. Higginson and M. Stauber. 1996b. Image analysis by geostatistical and neural-network methods - applications in glaciology. In Fourth Circumpolar Symposium on Remote Sensing of the Polar Environments, 29 April - 1 May 1996, Lyngby, Denmark. Noordwijk, European Space Agency, 87-91. (ESA SP-391.).

Kamb, B. and 7 others. 1985. Glacier surge mechanism: 1982-1983 surge of Variegated Glacier, Alaska. Science, 227 (4686), 469-479.

Lingle, C. S., A. Post, U. C. Herzfeld, B. F. Molnia, R. M. Krimmel and J. J. Roush. 1993. Correspondence. Bering Glacier surge and iceberg-calving mechanism at Vitus Lake, Alaska, U.S.A. J. Glaciol., 39 (133), 722-727.

Macdonald, K. C. 1982. Mid-ocean ridges: fine scale tectonic, volcanic and hydrothermal processes within the plate boundary zone. Annu. Rev. Earth Planet. Sci., 10, $155-190$.

Meier, M. F. 1960. Mode of flow of Saskatchewan Glacier, Alberta, Canada. U.S. Geol. Surv. Prof. Pap. 351.

Meier, M. F. and A. Post. 1987. Fast tidewater glaciers. 7. Geophys. Res., 92(B9), 9051-9058.
Molnia, B. F. 1993. Major glacier surge continues. EOS, 74(45), 521, 524

Molnia, B. 1994. Modern surge of glacier comes to an end. EOS, 75(47), 549.

Molnia, B. F. and A. Post. 1995. Holocene history of Bering Glacier, Alaska: a prelude to the 1993-1994 surge. Phys. Geogr., 16 (2), 87-117.

Post, A. 1972. Periodic surge origin of folded medial moraines on Bering piedmont glacier, Alaska. J. Glaciol., 11 (62), $219-226$.

Poston, T. and I. N. Stewart. 1978. Catastrophe theory and its applications. London, Pitman Publishing Limited.

Raymond, C. F. 1987. How do glaciers surge? A review. J. Geophys. Res., 92 (B9), 9121-9134.

Thom, R. 1972. Stabilité structurelle et morphogénèse. New York, Benjamin.

Tucholke, B. E. and J. Lin. 1994. A geological model for the structure of ridge segments in slow spreading ocean crust. 7 . Geophys. Res., 99 (B6), 11,937-11,958.

United States Geological Survey. 1983. Bering Glacier, Alaska. Fairbanks, AK, U.S. Geological Survey. (Topographic map, scale 1:250,000.)

MS received 29 March 1996 and accepted in revised form 29 March 1997 